\title{
PERPUSTAKAAN SEBAGAI WAHANA TERAPI YANG RAMAH DISABILITAS: \\ Implementasi Biblioterapi di Perpustakaan Lingkungan Pendidikan
}

\section{Oleh: Susanti Agustina}

Universitas Pendidikan Indonesia

susanti@upi.edu

\begin{abstract}
ABSTRAK
Biblioterapi salah satu metode terapi menggunakan media buku untuk rehabilitasi bagi klien panti sosial. Biblioterapi merupakan salah satu pengembangan pelayanan perpustakaan sebagai wahana terapi bagi masyarakat dengan berbagai latar belakang sosial budaya tanpa memandang keterbatasan fisik dan mental. Perpustakaan di lingkungan pendidikan menerapkan layanan biblioterapi yang ramah disabilitas bertujuan mendukung misi pendidikan untuk semua. Layanan biblioterapi di Indonesia masih menjadi hal baru, untuk itu kajian ini bermaksud membangun pemahaman yang menyeluruh tentang apa dan bagaimana biblioterapi, serta siapa yang melakukan biblioterapi di perpustakaan lingkungan pendidikan. Para tenaga perpustakaan maupun pustakawan di lingkungan pendidikan diharapkan mampu mengembangkan dan mengimplementasikan layanan biblioterapi bagi masyarakat. Terdapat enam tahapan implementasi biblioterapi yang ramah disabilitas di perpustakaan, pertama terkait pengembangan tata gedung perpustakaan yang ramah disabilitas; kedua pengembangan layanan perpustakaan; ketiga pengembangan pengadaan koleksi yang relevan untuk biblioterapi; keempat pengembangan pengolahan koleksi biblioterapi; kelima pengembangan SDM meliputi kualifikasi dan kompetensi tenaga teknis perpustakaan dan pustakawan yang berperan sebagai biblioterapist, Keenam manajemen dan praktik layanan biblioterapi di perpustakaan ramah disabilitas untuk membantu klien secara inklusif.
\end{abstract}

Kata kunci: perpustakaan khusus, biblioterapi, biblioterapist, disabilitas, perpustakaan sekolah, pendidikan 


\section{A. PENDAHULUAN}

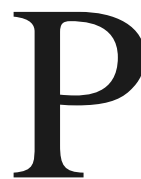

erpustakaan Kementrian Sosial sebagai Unit Pelaksana Teknis Kementrian Sosial RI, berjumlah 45 UPT Perpustakaan dan tersebar di 21 propinsi di Indonesia. UPT Perpustakaan Kemensos berada di bawah Balai Besar Diklat unit Badiklit Kemensos dan panti serta Balai di bawah Ditjen Rehabilitasi Sosial. UPT Perpustakaan Kemensos masuk dalam kategori perpustakaan khusus yang didirikan guna menunjang kegiatan di masing-masing UPT dan Balai juga masyarakat umum. UPT perpustakaan Kemensos memiliki Tugas pokok dan fungsi antara lain, menunjang tugas-tugas pegawai, melayani para klien di panti sosial dalam proses rehabilitasi sosial, juga masyarakat yang memerlukan informasi terkait layanan UPT dan program Kementrian Sosial.

Pada praktiknya UPT perpustakaan Kemensos telah menjalankan visinya sebagai pusat informasi kesejahteraan sosial dan wahana terapi, dengan menjalankan misi sebagaimana perpustakaan pada umumnya, yaitu manajemen, pengadaan, pengolahan, pelayanan dan peningkatan profesi pustakawan. Sebagai wahana terapi, perpustakaan Kemensos RI bersama UPT perpustakaan kemensos berupaya mengumpulkan dan mengelola sumber informasi bidang sosial, memberikan layanan informasi bidang sosial, meningkatkan jejaring kerja dalam pengembangan perpustakaan, mengembangkan layanan dan bahan pustaka terapi.

Sebagai upaya untuk memerkuat peran perpustakaan Kemensos dalam mendukung kinerja lembaga Kementrian Sosial, maka perlu adanya pembinaan dan pengembangan perpustakaan di lingkungan pendidikan sebagai pusat informasi kesejahteraan sosial dan wahana terapi yang ramah disabilitas. Upaya tersebut dapat menjadi pilot project sekaligus pelopor penerapan perpustakaan ramah disabilitas yang menerapkan layanan biblioterapi bagi klien panti rehabilitasi dan pemustaka umum. Mengingat di Indonesia belum ada perpustakaan percontohan yang secara serius memerhatikan perpustakaan di lingkungan pendidikan inklusi yang ramah disabilitas, terlebih untuk pelayanan biblioterapi yang masih asing bagi masyarakat di Indonesia.

Bila perpustakaan di lingkungan pendidikan berhasil mengimplementasikan perpustakaan ramah disabilitas beserta pengembangan layanan biblioterapinya, tentu akan sangat membantu perpustakaanperpustakaan kementrian sosial di 
Indonesia. Mulai dari perpustakaan umum, perpustakaan sekolah, perpustakaan perguruan tinggi maupun perpustakaan khusus sejenis lainnya untuk bersama-sama mewujudkan pendidikan untuk semua (education for all), sebuah perpustakaan inklusif yang ramah disabilitas.

\section{Latar Belakang}

Biblioterapi hingga 2014 ini masih belum populer di tengah masyarakat. Padahal di Barat sejak 1970 - 1980an perpustakaan rumah sakit sudah mulai memikirkan layanan biblioterapi bagi para pasien yang rawat inap, tidak hanya untuk para staf rumah sakit semata. Pustakawan di Rumah sakit tersebut berpikir bahwa pasien merupakan bagian dari layanannya sekaligus sebagai salah satu bentuk kepedulian terhadap masyarakat sebagai pertanggunganjawab sosial (social responsibillity ) atau dikenal sebagai layanan sosial (social service).

Layanan dimaksud, lebih mengarah kepada bantuan dan bimbingan bagi para pasien untuk meringankan beban penderitaannya. Karena sifatnya memberi bimbingan untuk membaca bacaan guna meringankan beban penderitaannya, maka disebut "Bibliotherapy" atau terapi lewat buku yang selanjutnya disebut " Reading Therapy" terapi menggunakan literatur (Clarke, 1990, p.49 ).
Pustakawan mengambil peran sebagai biblioterapist (orang yang melakukan biblioterapi) untuk membantu pasien, klien dan masyarakat secara luas dalam menyembuhkan atau meringankan beban penderitaan pasien melalui penyediaan bahan bacaan dan sekaligus membimbing penggunaannya.

Perawatan pasien lewat konsultasi dan mengarahkan dan mencarikan bacaan yang dianggap tepat bagi klien. Hal menarik, bahwa jika pada klien atau pasien yang masih mampu menyerap informasi bahan bacaan dipersilakan untuk membacanya sendiri, kemudian membimbingnya diskusi bersama. Berbeda dengan mereka klien pada umumnya, bagi para disabilitas atau seseorang yang membutuhkan bantuan khusus (disable people) adalah dengan cara dibantu melalui program layanan yang disebut "Guide to Read" (bantuan membaca) yang kegiatannya dilaksanakan secara mingguan, seperti baca puisi, prosa, bacaan pilihan juga dibantu dengan keberadaan permainan mendidik yang menarik dan berguna (educative games ).

Bagi kelompok khusus (subgroup), yaitu disable people (kelompok pasien yang berkebutuhan khusus ) ada lima kelompok pasien yang dikategorikan sebagai " disable people", yaitu: mereka yang memunyai keterbatasan penglihatan, pendengaran, fisik, sakit mental ( gangguan 
jiwa ) dan keterbelakangan mental. Reading therapy dapat mencakup bagi seluruh klien baik bagi klien biasa, anak-anak, dan mereka yang berkebutuhan khusus.

Sebagai contoh kasus bagi mereka yang mendapat gangguan jiwa ( stres ) dari berbagai penyebab, pendekatan penanganannya dilakukan secara individual atau perorangan, namun apabila kadarnya sama dapat dilakukan melalui kelompok kecil (3) orang pasien. Bagi mereka yang mendapat gangguan psikologi gangguan ringan dapat dilakukan dengan berkolaborasi antara pustakawan, psikolog, dan dokter psikiater.

Pustakawan menyediakan bacaan, psikolog, mencari akar penyebab timbulnya gangguan dan psikiater cara pengobatannya. Akan tetapi untuk kasus tertentu pustakawan dapat melakukannya sendiri dengan mengambil catatan medisnya kepada bagian rekam medis (medical record) tentang kasusnya, kemudian melakukan dialog dengan pasien tersebut untuk selanjutnya melakukan reading therapy.

$$
\text { Perkembangan berikutnya }
$$

"Reading therapy" tidak hanya dilakukan oleh perpustakaan rumah sakit, tapi dapat dilakukan oleh jenis perpustakaan apapun, seperti perpustakaan sekolah lewat program bimbimgan konseling ( BK ), perpustakaan perguruan tinggi lewat program "Reading
Advisory Service" ( Bimbinan pembaca ), sedangkan bagi perpustakaan umum maupun khusus, lewat program pelayanan sosial (Social Service) yang merupakan program dinas sosial menangani berbagai penyakit sosial.

Contoh kasus mengapa Bimbingan Konseling di berbagai institusi atau lembaga pendidikan gagal membawa perubahan perilaku pada klien, salah satu penyebabnya adalah terapist tidak menggali akar permasalahannya, konseling lebih kepada tindakan sesaat tanpa bermaksud menyelesaikan akar permasalahan sebagai inti dari munculnya berbagai keluhan perilaku stres dan depresi tersebut.

Terapis maupun konselor lebih menekankan pada hukuman atau pemberian nasihat-nasihat, yang sesungguhnya tidak efektif. Mengapa tidak efektif? Sebab tidak diketahui akar permasalahannya di samping jiwa manusia yang anti nasihat. Jiwa manusia cenderung tidak suka diperintah dan dinasihati. Maka, salah satu alasan mengapa kitab suci diturunkan hampir 60 $\%$ isinya berisi kisah, mungkin dimaksudkan agar manusia dapat mengambil hikmah dan pelajaran bukan lagi perintah atau larangan.

Hal tersebut sejalan dengan konsep biblioterapi, dimana proses terapi dilakukan menggunakan buku atau kisah dari buku yang dibacakan dan didiskusikan sehingga 
membangun simpulan atas permasalahan tersebut dari alam bawah sadar. Penyelesaian masalah berasal dari dalam diri klien, bukan rekomendasi mutlak dari terapist yang pada dasarnya belum tentu diterima oleh klien.

Boleh jadi klien mengiyakan nasihat terapis, tetapi jika persetujuan itu hanya di permukaan saja, bisa dipastikan klien akan tetap bermasalah. Permasalahan belum tuntas. Kalau diketahui akar permasalahannya misalnya akibat beban belajar yang berat, stres karena tidak dapat mengatur prioritas dan waktu atau gangguan di rumah (keluarga) semisal perceraian orangtua yang notabenenya akan mengganggu proses belajar, maka psikolog dapat berkolaborasi dengan pustakawan untuk menanganinya, misalkan konselor dengan pendekatan konselingnya dan pustakawan dengan terapi buku, biblioterapinya (reading therapy).

Dengan adanya program layanan biblioterapi, semua permasalahan sosial dapat diatasi bersama secara kolaboratif antara pihak pustakawan di perpustakaan lingkungan pendidikan dengan pihak terkait, seperti dinas sosial, konselor, psikolog, atau pengasuh di panti. Sayangnya program Bibliotherapi atau Reading therapy belum populer apa lagi dilaksanakan di perpustakaan lingkungan pendidikan, terlebih lingkungan pendidikan inklusi.

\section{B. PERUMUSAN MASALAH}

Dari latar belakang masalah di atas dapat dirumuskan sebagai berikut:

1. Bagaimana Implementasi biblioterapi yang ramah disabilitas di perpustakaan lingkungan pendidikan?

2. Bagaimana pengembangan tata gedung perpustakaan di lingkungan pendidikan yang ramah disabilitas?

3. Bagaimana pengembangan layanan perpustakaan di lingkungan pendidikan?

4. Bagaimana pengembangan pengadaan koleksi yang relevan untuk biblioterapi?

5. Bagaimana pengembangan pengolahan koleksi biblioterapi?

6. Bagaimana pengembangan SDM meliputi kualifikasi dan kompetensi tenaga teknis perpustakaan dan pustakawan yang berperan sebagai biblioterapist?

7. Bagaimana manajemen dan praktik layanan biblioterapi di perpustakaan lingkungan pendidikan yang ramah disabilitas untuk membantu klien secara inklusif?

\section{Pengertian Istilah}

Bibliotherapy bukanlah terapi tunggal, anda harus melatih gaya komunikasi anda bersama klien. Bangun hubungan emosional dengan klien. Ibaratnya, buku adalah tiket anda untuk berwisata dari satu peristiwa ke peristiwa lainnya di dimensi kehidupan yang kaya ragamnya. "... geting the right book to the right child at the right time about the right problem.( Lundsteen, 1972 dalam Abdullah, Madziah Hayati, 2002 ). 
Bagaimana mungkin anda bisa nyaman bertamasya dengan seseorang yang tidak anda suka, tidak anda kenal, bahkan bisa dikatakan tidak "ngeklik" dengan anda? Tentu sangat tidak nyaman. Seperti yang dikatakan Russell dan Shrodes tentang biblioterapi, bahwa biblioterapi sebagai proses dinamis untuk mengenali karakteristik individu. " ... a process of dynamics interaction between the personality of reader and literature, interaction which may be utilized for personality assessment, adjudment, and growth." (Russell dan Shrodes, 1950 dalam Alex Kortmer, 2006).

Saat di perjalanan, peran anda sebagai guide yang mengasyikan. "... helping a pupil find book that might help the pupil solve a personal problem, develope skill needed for living, and /or bolster self- image."( Shepherd dan Iles, 1976 dalam Alex Kortmer, 2006)

Bukan guide yang sok mengatur atau sok tahu. Anda adalah guide yang mampu mengasah rasa ingin tahu klien sehingga sama-sama menemukan keindahan saat di perjalanan, memaknai setiap tempat yang dikunjungi, mengambil hikmah dari karakter setiap orang yang ditemui, hingga saat pulang anda bersamasama kembali tercerahkan, kembali membersihkan kepenatan, dan mengantongi pengalaman mengesankan. "... Psychology through literature - reading that its used to help solve prevent problems." ( Stedel, 1964. dalam Abdullah, Madziah, 2002 ). Kiranya begitulah semestinya analogi dari terapi buku ini. Analogi wisata.

Biblioterapi bertujuan membantu seseorang memecahkan permasalahannya melalui literatur, buku, dan sumber informasi lainnya (Biblio). Penggunaan berbagai sumber bacaan atau literatur untuk memecahkan permasalahan yang berkaitan dengan emosional, dan penyakit mental atau membantu mengubah perilaku seseorang untuk mencapai kehidupannya.

Intinya biblioterapi memberikan layanan kepada seseorang dalam mencapai tujuan hidupnya yang sedikit mengalami hambatan baik emosional maupun mental. Di lingkungan pendidikan inklusi (karena fungsi perpustakaan sebagai sarana pendidikan), merupakan teknik yang digunakan kaitannya dengan program pengajaran ( kurikulum berbasis bakat ) mempertemukan antara media pembelajaran dengan para murid disabilitas dari panti-panti sosial yang sedang mengikuti, mempelajari, mengerjakan dan membahas tugas atau kasus tertentu sebagai ujian sekolah, dalam prosesnya mereka rentan mengalami kendala, jika lingkungan tidak mendukung maka bisa mengarah pada stres. Dapat juga dikaitkan dengan pembimbingan mereka memecahkan 
berbagai kasus, baik kaitannya dengan belajar maupun faktor lain tentang dirinya melalui penyediaan literatur atau media Instruksional (Cornett at all, 1980 ).

Dalam kasus tertentu bibilioterapi tidak hanya digunakan untuk menangani permasalahan Instruksional saja akan tetapi dapat digunakan untuk menangani permasalahan psikologis sebagai dampak dari proses pembelajaran dan faktor lingkungan, seperti depresi, kejenuhan, stres, dan frustrasi bekerja sama antara pustakawan, pendidik, psikolog, dan pihak terkait, tentunya penanganannya melalui penyediaan bahan bacaan yang sesuai. Siapa yang paling berwenang dan dianggap ahli memilih dan memilah buku? Pustakawan.

Dengan kata lain bibilioterapi merupakan salah satu bentuk layanan perpustakaan untuk menangani kasus di kalangan pemustaka baik bersifat preventif maupun kuratif. Preventif dalam rangka mencegah agar mereka tidak mengalami permasalahan dalam penyelesaian dan pencapaian tujuan hidup dan pendidikannya, kuratif mencoba membantu memecahkan permasalahannya yang keseluruhannya dilakukan lewat bahan bacaan atau literatur. Sehingga bibilioterapi dapat dijadikan alternatif layanan perpustakaan di lingkungan pendidikan, sekaligus menjawab tentang pertanyaan kapan Biblioterapi digunakan, ialah sebelum atau sesudah para klien mengalami permasalahan dalam penyelesaian kasusnya. Penanganan sebelum terjadi permasalahan disebut Preventif dan setelah terjadi disebut Kuratif. (McNamee, 1996).

\section{Implementasi Biblioterapi di} Perpustakaan Lingkungan Pendidikan

Menerapkan konsep layanan biblioterapi khususnya untuk penyandang disabilitas terlebih dahulu harus mengenali apa dan siapa orang berkebutuhan khusus. Mengapa perlu dikenali? Sebelum saya membahas lebih lanjut terkait pengguna perpustakaan di lingkungan pendidikan, saya sampaikan bahwa penggunaan kata disabilitas, bagi penulis memang terasa kurang sesuai. Disability, Disabilties, Disable, memiliki arti harfiah terjemahan Bahasa Indonesia yang berarti tidak mampu, tidak bisa, tidak berdaya.

Sementara kita perlu bertanya mereka tidak mampu, pada saat apa mereka tidak mampu? Pada saat apa mereka tidak bisa, dalam hal apa? Bisakah anda menyebut mereka tidak berdaya, sementara kita yakin bahwa apapun yang Tuhan ciptakan di dunia ini tidak ada satu pun yang sia-sia. Bahkan seekor lalat sekalipun, keberadaannya tetap memberi manfaat. Kebermanfaatan itu erat kaitannya dengan bakat, dan kemampuan setiap individu dalam berkontribusi terhadap 
lingkungannya. Benarkah mereka tidak mampu, tidak berdaya, tidak bisa?

Penulis ingat tentang ilmu Neurology Linguistic Programming, yang intinya bahwa dalam berkomunikasi, ambillah istilah atau kata-kata sesuai dengan budaya otak manusia. Maksudnya, otak akan menyimpan setiap informasi apapun yang didengar, diketahui, dan dikatakan secara berulang-ulang. Misalkan kita menyebut mereka, anda, dan semua orang di lingkungannya menyebut mereka disabilitas, apa yang mereka yakini? Mereka yakini bahwa mereka tidak mampu, tidak bisa, tidak berdaya. Sama halnya dengan kita telah mengimplant data terhadap otak klien yang "disabilitas" sebagai seorang “disabilitas. Bukankah sebaiknya kita menamakan mereka orangorang yang berkebutuhan khusus? Kebutuhan mereka khusus, bukan berarti mereka tidak berdaya. Jadi mulailah dengan mengafirmasi kondisi mereka dengan istilah atau kata-kata yang "ramah" di benak mereka.

Apa anda sepakat dengan pendapat tersebut?, beritahu penulis tentang pengalaman dan pemahaman anda yang intensitas berinteraksi sehari-harinya dengan mereka. Apa mereka nyaman dengan sebutan disabilitas? Untuk sementara sampai tiba adanya kesepakatan mengenai penamaan tersebut, izinkan penulis masih menggunakan istilah “disabilitas” untuk menunjukkan klien dalam kegiatan layanan biblioterapi di perpustakaan lingkungan pendidikan.

Sebelum kita mengembangkan perpustakaan yang ramah “disabilitas" mengapa kita perlu mengenali? Antara lain agar kita dapat mengoptimalkan intervensi dan proses biblioterapi/ reading therapy di perpustakaan, melakukan penyesuaianpenyesuaian untuk dapat memenuhi hak klien, dapat melakukan identifikasi karakteristik, kebutuhan, cara belajar, dan minat klien agar pelaksanaan terapi berjalan efektif, efisien, dan bernilai guna bagi mereka.

Sementara ini, untuk membangun perpustakaan khusus bagi klien berkebutuhan khusus bisa saja diupayakan. Namun, justru mereka para klien sangat mengharapkan keberadaannya diterima, secara hangat, ramah dan terbuka. Adanya upaya dari lingkungan untuk menjadikan mereka orang-orang yang “penting”, yang layak untuk tumbuh dan berkembang sesuai dengan kelebihan mereka masing-masing. Ketika kita menunjukkan kepercayaan penuh bahwa mereka bisa mandiri dan dekat kita tanpa syarat, mereka bahagia. Mereka merasa hak mereka dihargai. Belajar bersama, bermain bersama, berinteraksi bersama orang-orang di lingkungannya. Sebab perlu dikenali bahwa 
klien terdiri dari beberapa karakteristik, antara lain adanya hambatan kognitif, berkaitan dengan kemampuan akademik, adanya hambatan kemampuan sosialemosional yang berkaitan dengan sikap perilaku, adanya hambatan fisik dan sensoris yang berkaitan dengan berkurang atau hilangnya fungsi penglihatan, pendengaran, dan kemampuan bicara; adanya hambatan perkembangan mental dan spektrum autisma (Adnan dkk, 2012).

Perhatian terhadap orang berkebutuhan khusus sudah terjadi cukup lama dan pada abad 16 mulai terjadi perubahan sikap yang lebih positif terhadap masalah orang berkebutuhan khusus ini, seperti rumah sakit di Paris mulai menyediakan layanan bagi penderita gangguan emosional, mulai adanya manual abjad yang pertama bagi penyandang tuli. Dr. Maria Montessori membuat metode pembelajaran yang khusus bagi anak dengan keterbelakangan mental, Helen Keller yang seorang tunanetra memberikan perhatian khusus pada penyandang cacat penglihatan, dan banyak lagi yang lainnya, yang mampu memberikan inspirasi banyak orang tentang bagaimana memberikan perhatian pada para penyandang cacat agar mereka dapat hidup sebagaimana layaknya orang lain. Penanganan klien disabilitas dalam biblioterapi bisa dilakukan sebelum terjadi permasalahan, disebut Preventif dan setelah terjadi disebut Kuratif. (McNamee, 1996).

\section{Preventif}

Preventif adalah suatu cara pendekatan penananganan terapi sebelum terjadi kasus, dalam hal ini sebelum klien mengalami stres, depresi dan gangguan mental yang disebabkan oleh beragam faktor. Kegiatannya dapat berupa bimbingan pembaca dan Pendidikan pemakai. Misalnya dilakukan di awal masuk asrama ketika mereka sedang orientasi sebelum masuk pembelajaran di panti, atau diadakan program tahunan salah satu bentuk kegiatan perpustakaan yang namanya Pendidikan pemakai (user education), yaitu mendidik mereka tentang bagaimana memanfaatkan perpustakaan (How to use the library) seperti bagaimana cara mengakses buku atau informasi di perpustakaan. Di dalamnya juga diberikan informasi tentang teknik pemanfaatan sumber tersebut dan bagaimana tata cara meminjam dan mengembalikan buku, terutama lebih diarahkan pada kegiatan-kegiatan di perpustakaan yang secara interaktif melibatkan mereka. Mereka terus dibimbing sehingga tidak mengalami kesulitan dalam menyelesaikan tugas- tugas hariannya, baik di rumah maupun sekolah/yayasan.

Mereka dapat mandiri dan tidak bergantung lagi pada staf perpustakaan dan 
sekaligus optimalisasi penggunaan sumber informasi di perpustakaan. Pada fase ini diinformasikan juga tetang tata cara memanfaatkan tempat/ ruangan perpustakaan yang berisikan media rekreatif seperti; koleksi musik, film, bacaan hiburan, ruang santai dan rileks, juga ruang khusus layanan biblioterapi. Tempat ini dirancang untuk memfasilitasi mereka mengembangkan interaksi sosial emosional dan relaksasi.

\section{Kuratif}

Kegiatan ini dilakukan apabila telah terjadi kasus seperti stres, depresi, dan gangguan psikologi lainnya. Berbagai langkah bisa dilakukan bergantung kepada kondisi dan situasi klien. Adapun tahaptahapnya sebagai berikut:

\section{Tahap persiapan}

Pada fase ini kegiatan Biblioterapi dipadukan pada membangun kedekatan emosi dengan klien. Di dalamnya sekaligus memberikan motivasi, dorongan dan memberikan rasa aman serta membantu pengembangan dirinya, juga dapat memecahkan permasalahannya sendiri.

\section{Pembentukan kelompok Diskusi}

Pada fase ini pustakawan dan pihak terkait melakukan identifikasi kebutuhan klien. Mereka yang membutuhkan bantuan yang sama atau mirip dikelompokkan dalam satu kelompok, sedangkan yang berbeda akan terkelompok pada kelompok lainnya. Hal ini dimaksudkan agar penanganan permasalahannya dapat dilakukan serempak. Selain itu berkaitan dengan penyediaan bahan bacaan bagi penanganan permasalahannya agar tidak terjadi duplikasi.

\section{Mendesain Bahan Diskusi}

$\begin{array}{ccc}\text { Dalam } & \text { pengembangan } & \text { sistem } \\ \text { pembelajaran } & \text { kaitannya } & \text { dengan }\end{array}$

Biblioterapi, pustakawan terlebih dahulu mendiskusikan dengan pihak terkait. Inti dari Biblioterapi adalah problem solving, membantu mereka mengatasi permasalahannya, menciptakan kreativitas dan atmosfir untuk mencapai kesuksesannya.

\section{Implementasi Pelayanan Biblioterapi}

Biblioterapi dalam implementasinya perlu diintegrasikan dengan pembelajaran dan pembiasaan di panti, rumah, sekolah atau sebagai program tersendiri. Biblioterapi merupakan program yang secara intensif diberikan kepada klien panti sosial/ rehabilitasi. Upaya pengadaan koleksi dan fasilitas untuk mendukung layanan biblioterapi harus menjadi prioritas di samping tenaga SDM yang mumpuni untuk dapat dilatih 
menjadi biblioterapist handal. Biblioterapist itu kemampuan yang bisa dilatih, asalkan yang bersangkutan memiliki panggilan jiwa.

\section{Tindak Lanjut Aktivitas Biblioterapi}

Inti kegiatan tersebut adalah menyediakan sumber biblioterapi untuk para klien “disabilitas” memecahkan permasalahannya. Dapat dilakukan dengan berbagai cara diantaranya melalui, seperti diungkapkan (McNamee, 1996, p. 1-24 ) sebagai berikut :

\section{Penulisan kreatif}

Setiap klien mencoba memecahkan berbagai permasalahannya lewat tulisan atau karangan bebas dan karya tulis populer itu didiskusikan. Bentuk tulisan bisa prosa, puisi, autobiografi, dan tidak menutup kemungkinan dalam bentuk novel.

\section{Bentuk Karya Seni}

Bentuknya bisa berupa gambar atau lukisan tentang dirinya dan bisa pula dalam bentuk peta tentang perjalanan hidupnya. Ini pun sama dikonstruksikan dalam bentuk diskusi, diskusi bisa berlangsung secara privat, maupun kelompok kecil. Melalui karya seni, klien dapat memecahkan permasalahannya, di samping karyanya akan bermanfaat untuk orang lain. Pada teknik ini pustakawan membantu menyediakan literaturnya.

\section{Pemecahan masalah dan Bermain Peran}

Metode ini dapat melibatkan klien lain bisa dalam kasus yang sama atau berbeda. Mereka menceritakan problemnya masing-masing, kemudian mencari literatur yang tepat untuk pemecahannya, dapat juga dilakukan setiap klien menghadapi kasus klien lainnya, klien mencari misalnya 10 literatur untuk memecahkanya , kemudian diberi waktu 1 atau 2 jam sampai terselesaikan kasus tersebut. Hasilnya dipresentasikan, didiskusikan, dikomentari dan dievaluasi. ( McNamee et al, 1996 ).

Tindakan-tindakan tersebut di atas, tentu saja disesuaikan dengan situasi dan kondisi klien juga terapist. Bila memungkinkan, beberapa pilihan kegiatan bisa dijadwalkan selama satu minggu. Peserta biblioterapi diutamakan hasil rekomendasi pembimbing/pengasuh yang tahu pasti kondisi klien.

\section{Pengembangan Tata Gedung perpustakaan yang ramah disabilitas}

Perpustakaan di lingkungan pendidikan yang ramah disabilitas, tentu membutuhkan manajemen perencanaan gedung yang didesain berdasarkan kriteria kebutuhan para penyandang disabilitas sebagai pengguna. Paling tidak, untuk mengimplementasikan sebuah gedung perpustakaan inklusi (ramah disabilitas), perlu memerhatikan kepentingan utama 
yang memudahkan akses para disable. Halhal yang penting diperhatikan untuk gedung perpustakaan yang ramah disabilitas (Agustina, 201, p.9), antara lain:

1. Akses masuk perpustakaan, dengan tangga roller untuk akses roda.

2. Pintu masuk otomatis, sehingga memudahkan keluar masuk.

3. Terdapat lift untuk memudahkan naik turun antar lantai.

4. Toilet khusus untuk orang berkebutuhan khusus berada di lantai dasar

5. Ruang biblioterapi yang lebih luas dan leluasa, idealnya dilengkapi bola besar untuk duduk saat diskusi berlangsung

6. Dinding-dinding yang dilapisi busa, agar lebih aman.

7. Fasilitas lainnya yang mendukung.

Perpustakaan inklusif tidak lantas membedakan akses orang pada umumnya dengan para berkebutuhan khusus. Justru, segala sesuatunya didesain seperti perpustakaan biasa, ruangan-ruangan yang sesuai dengan fungsi layanan perpustakaan. Biasanya layanan biblioterapi berada di layanan koleksi referensi. Namun, jika terpisah, ini lebih baik dan akan lebih maksimal. Ruangan biblioterapi sendiri, bisa dibagi menjadi :

1. Ruang Diskusi Kelompok Kecil

2. Ruang Diskusi Kelompok Besar

3. Ruang Terapi Individu

4. Ruang Biblioterapist

5. Ruang Koleksi Biblioterapi

6. Ruang Alat Permainan Edukatif

7. Ruang Simpan Karya

8. Ruang Dokumentasi dan arsip klien

9. Ruang Relaksasi dan Hypnotherapy

10. Ruang Multimedia Inklusi
11. Ruang Konsultasi

Ruangan tersebut bisa berupa pojok/ corner walaupun idealnya memenuhi setiap kebutuhan ruangan. Kalaupun bagian ruangan di perpustakaan masih sangat terbatas, pada prinsipnya biblioterapi bisa dilakukan di satu ruangan saja. Dengan menyediakan kursi lipat, atau bola duduk khusus untuk orang berkebutuhan khusus. Bahkan lesehan dengan alas karpet pun menjadi sangat menyenangkan. Lebih leluasa justru akan lebih baik. Ruangan dilengkapi sound sistem yang akan memerdengarkan musik relaksasi untuk hypnosis, akan sangat membantu. (Agustina, 2014, p.9) Beberapa yang direkomendasikan oleh Badan Internasional Bangunan Bagi Anak- Anak Berkebutuhan Khusus (Comittee The Children's Aid Association) sebagai berikut :

\section{Fasilitas Fisik}

Fasilitas fisik perpustakaan mencakup segala yang berkaitan dengan gedung dan segala perabotannya seperti:

1. Tempat Parkir khusus

2. Tangga khusus

3. Ramp atau pelindung

4. Elevator

5. Pintu khusus; terbuka dan sendiri

6. Pencahayaan interior gedung yang disesuaikan dengan kondisi mereka

7. Toilet khusus (adapted toilet) 

8. Ruang baca khusus yang disesuaikan dengan kondisi mereka.

\section{Fasilitas Layanan Bibliotherapi}

Fasilitas layanan untuk membantu mereka yang sakit psikis meliputi:

1. Buku Hiburan dan Relaksasi (penyediaan buku untuk mengisi waktu istirahat) maksud dari layanan ini adalah penyediaan ruangan buku (book holder ) dan atau bacaan yang bersifat rekreatif, seperti puisi, novel, cerita, majalah hiburan, Surat kabar, tabloid dan jenis lainnya termasuk film dan musik. Inti penyediaan ruangan ini, klien/pemustaka merasakan suasana layaknya di rumah sendiri (home stay).

Fasilitas yang disediakan meliputi:

a. Meja baca dalam berbagai bentuk dan ukuran biasanya ukuran kecil termasuk juga study carrel ( Meja baca tertutup)

b. Tempat tidur terapi dan juga sofa nyaman agar mereka dapat membaca sambil santai dan selonjoran atau rileks

c. Karpet dan bantal-bantal ukuran besar dan kecil, agar mereka dapat membaca santai

d. Ruangan musik dan film, tempat ini ditata sebagai tempat mendengarkan dan nonton film. Tentunya diatur dengan menggunakan alat kedap suara. (Sharman dalam Clarke, 1990, p.86-92)

e. Mesin buku disebut juga buku bicara. (Book pen)

f. Alat merekam, candid camera. g. Reading service; layanan membaca yaitu biblioterapist / staf perpustakaan membacakan buku yang dipinjam oleh mereka.

h. Reading guide; Hampir mirip dengan reading service, yaitu membantu menemukan buku yang akan mereka baca.

i. Headsets (alat mendengar).

j. Buku atau bahan bacaan yang menggunakan huruf Braille, bagi tunanetra.

\section{Pengembangan Layanan Perpustakaan di Lingkungan Pendidikan}

Hal yang dibicarakan pada konteks ini adalah permasalahan psikologis kaitannya dengan pembaca dan bagaimana penanganannya, seperti: kecemasan, rasa takut (anxiety states), depresi, phobia, obsesi, dan tekanan. Selain daripada itu faktor- faktor yang berhubungan dengan hubungan manusiawi seperti; konflik, putus cinta, problem keluarga, dan kekesalan. Selanjutnya yang disebabkan oleh situasi kenilangan kendali atau trauma seperti; kehilangan sesuatu, gelisah, dampak pelecehan seksual, bullying dan sakit fisik. Penyembuhan dapat dilakukan, diantaranya dengan :

1. Rileksasi bagi pembaca yang mengalami anxiety ( rasa takut), sistem pemusatan pikiran bagi yang phobia.

2. Diskusi bisa kelompok bisa juga individual bersama pembimbing biblioterapi berbagi masalah dan 
mencari solusinya. Hal ini dapat menghilangkan perasaan takut, khawatir, prediksi yang berlebihan dan msalah terkait lainnya.

3. Mengalihkan permasalahan lewat bacaan, musik dan menonton film.

4. Tour atau jalan-jalan melihat pemandangan, ke luar ruangan (outing).

(George, Heather dalam Klarke, 1982, p. 116-122).

Inti dari Biblioterapi sederhana, yaitu penggunaan buku untuk membantu seseorang memecahkan dan menjelaskan permasalahannya. Dengan penekanan pada identifikasi permasalahan yang dihadapi untuk selanjutnya dirujuk kepada literatur yang disesuaikan dengan karakter permasalahan yang dihadapinya itu. Lalu dihubungkan dengan kondisi emosi klien agar dapat diarahkan ke sumber bacaan yang dapat dibaca dan dapat megarahkan ke dalam pencapaian hidupnya, serta memberikan tentang tata cara penyelesaian baru dan dapat lebih berinteraksi dengan pihak lain, lebih terbuka dengan tidak menutup diri. ( Abdullah, 2002 dalam Schreur, 2006 , p.108, dalam Agustina, 2014, p.11)

\section{Pengembangan Pengadaan Koleksi yang} Relevan untuk Biblioterapi

Mencermati klien pengguna perpustakaan yang berkebutuhan khusus karena faktor kognitif dan emosional seperti tuna grahita yang jumlahnya cukup banyak sehingga perlu untuk dikaji secara lebih mendalam tentang kebutuhan akan media bacaan dan layanan informasi, khususnya yang diberikan oleh perpustakaan lingkungan pendidikan.

Mereka yang memerlukan bantuan khusus sepeti tuna grahita apabila dipandang secara fisik normal, namun tingkatan kecerdasan dan intelektualnya yang membutuhkan pendekatan intensif yang lebih besar, jika dibandingkan dengan yang klien berkebutuhan khusus lainnya.

Kondisi koleksi pustaka yang dimiliki oleh perpustakaan umum maupun sekolah jarang sekali yang diperuntukan bagi pemustaka yang berkebutuhan khusus. Sebagai gambaran sebanyak 354 ribu judul koleksi pustaka di perpustakaan Bapusipda Propinsi Jawa Barat kurang dari 0.50 \% koleksi bagi pemustaka yang berkebutuhan khusus. Demikian juga kondisi koleksi perpustakaan pada sekolah luar biasa yang multi kebutuhan, koleksinya minim, di bawah 1.500 judul dengan kondisi yang sangat memprihatinkan dan tidak terurus di samping belum ada pustakawan khusus yang menanganinya.

Kebijakan pemerintah propinsi Jawa Barat tentang penyediaan bahan bacaan bagi mereka yang berkebutuhan khusus belum optimal, masih sebatas penyediaan sarana fisik non perpustakaan. Apalagi penyediaan tenaga professional 
bidang perpustakaan yang masih belum terperhatikan.

Perpustakaan di lingkungan pendidikan perlu melakukan identifikasi koleksi yang layak bagi pelaksanaan biblioterapi. Pada dasarnya semua buku, baik fiksi maupun non fiksi layak untuk terapi, hanya saja genre buku-buku motivasi, sastra, cerpen atau novel perlu diperbanyak.

Bahan bacaan menjadi media penanaman karakter pada anak. Di dalam buku, dapat kita temukan karakter sastra. Sastra tidak dapat lepas dari kehidupan manusia. Buku sastra (literature) memberikan pemahaman bagi klien berkebutuhan khusus untuk pertama kalinya mengenai arti menjadi manusia. Walaupun sastra hanya menjadi cerminan bukan realita, sebab bagaimana pun seseorang sebaiknya memahami kehidupan secara nyata, mengindera semuanya secara alami. Namun, buku mampu menembus batas-batas usia dan kondisi mental dan budaya mereka (Agustina, 2014, p.12).

Dengan dibacakannya kisah sastra, mereka menyelami alam kehidupan lain yang sesungguhnya belum mereka jejaki. Itulah mengapa ada slogan yang mengatakan, membaca membuka jendela dunia. Klien berkebutuhan khusus akan menarik sebanyak-banyaknya pengalaman yang bahkan belum mereka alami. Klien berkebutuhan khusus lahir ke dunia melalui masa-masa keemasannya dengan rasa ingin tahu yang besar. Masa mengeksplorasi keajaiban-keajaiban, melambungkan imajinasi, semuanya untuk bekal mengetahui siapa dan apa yang akan dilalui dalam hidup, kemandirian.

Kehidupan dalam kisah membuat mengetahui dirinya, dunia dan mulai melihat dunia sebagai sesuatu yang lebih dari yang ia bayangkan, klien berkebutuhan khusus belajar beragam karakter dalam kehidupan, mungkin mengenali bagaimana mengantisipasi atau mengatasi sesuatu bahaya yang mungkin mengancamnya.

Peristiwa dalam kisah adalah suatu cara eksplorasi dunia, membantu klien berkebutuhan khusus untuk konfirmasi , untuk menerangi, dan untuk memerluas pengalaman hidup sendiri, memberikan mereka ruang untuk menentukan sikap dan cara terbaik. Kisah memberi bentuk umum untuk makna pribadi. Semua itu membantu mereka yang menerima pesan yang menjangkau manusia lain di dunia, mengetahui bahwa mereka berbagi beberapa kekhawatiran dan perasaan yang sama.

Adapun yang tidak kalah penting adalah narasi informasi. Narasi juga bentuk penting dari sastra anak-anak dan remaja. Sastra anak adalah cara untuk memahami dan menghargai dunia anak-anak dan siapa pun yang berbagi dengan anak-anak. Semua orang perlu belajar tentang 
kehidupan, baik secara harfiah, harafiah, dan estetika.

Apabila pustakawan biblioterapist hendak menemukan buku bacaan yang akan digunakan sebagai media biblioterapi, sebaiknya memerhatikan aspek-aspek berikut :

- Format Buku: Buku Karton, Kertas tebal, Buku Berjaket, Buku Pop up (Buku Meletup, buku yang disertai bulu, dan 3-4 dimensi).

- Aspek Genre Buku Fiksi: Legenda, dongeng, qisah petualangan, kisah humor/ lucu, Cerita Pendek.

- Tema Khusus dari Buku Non Fiksi: Ensiklopedia Bocah Muslim banyak tema

- Usia Pembaca: Tahapan perkembangan kognitif kanakkanak awal, akhir, remaja awal, akhir, tempat/ lokasi pembaca, ketertarikan berdasarkan usia, tahapan sekolah anak.

- Kemampuan dan Ketidakmampuan dari Pembaca: Pengulangan, Berkebutuhan Khusus, bacaan yang ringan.

- Kode dan Simbol: Skema Klasifikasi Dewey, Pelabelan warna pada masing-masing pembaca berdasarkan usia, Kode warna berdasarkan subjek isi buku. colour, kode gambar.

- Seri Penerbitan, Fiksi dan Buku Informasi.

- Kelompok Kategori: Berdasarkan bahasa, kepopuleran, isi multi kultural.

(Marshall, 1988, p.60 dalam Agustina, 2014, p.12)

Jenis-jenis Buku Fiksi dan Non Fiksi Anak

- Mite, legenda, Cerita Rakyat dan dongeng
- Fantasi dan Hantu

- Fabel

- Sejarah

- Humor, komik dan potongan gambar

- Qisah sehari-hari

- Qisah petualangan

- Qisah keluarga

- Qisah nyata

- Chiklit, teenlit

- Kumpulan puisi/ prosa

- Buku permainan

- Buku informasi

(Margaret R Marshal, 1988, p.60 dalam

Agustina, 2014, p.12)

\section{Pengembangan Pengolahan Koleksi Biblioterapi}

Untuk perpustakaan di lingkungan pendidikan yang inklusi, sebenarnya hanya tinggal menambah simbol pada buku-buku tertentu khusus biblioterapi. Hanya memang akan menambah pekerjaan baru bagi bagian pengolahan. Koleksi tidak perlu disimpan di ruang referensi atau bagian layanan lain, apabila telah diidentifikasi memenuhi syarat untuk biblioterapi, sebaiknya dilokasikan di rak khusus untuk koleksi biblioterapi agar lebih memudahkan layanan biblioterapi. Kemungkinan jika koleksi berdasarkan subjek buku tertentu, bisa dijadikan duplikasi buku. Maksudnya, koleksi tersebut bisa kita temui di layanan sirkulasi, referensi, dan biblioterapi. Idealnya begitu. Karenanya, ketika perpustakaan akan migrasi menuju perpustakaan inklusi, pengadaan koleksi dan pengolahan koleksi 
mulai dari nol, yang khusus untuk biblioterapi.

Pengolahan koleksi dilakukan penomoran klasifikasi, menambahan simbol BT (Biblioterapi), dengan tambahan label warna, misalnya warna ungu untuk koleksi biblioterapi fiksi, warna kuning untuk biblioterapi non fiksi. Atau secara detail berdasarkan genre buku bacaannya. Setelah diklasifikasi, pelabelan, penyampulan, dan dilakukan input data koleksi terotomasi, bagi mereka penyandang tunanetra lebih baik jika ada fasilitas software khusus yang mengonversi sandi kata tulisan ke dalam bentuk braile. Contohnya Jaws, program pembaca layar untuk tunanetra, iBlind ponsel khusus tunanetra, atau perangkat computer khusus tunanetra, Pertuni. Produk luar negeri, seperti screen readers pun sebaiknya tersedia untuk memudahkan mentransfer informasi ke dalam bentuk suara.

\section{Pengembangan SDM Biblioterapist}

Pengembangan Sumber Daya Manusia, meliputi kualifikasi dan kompetensi tenaga teknis perpustakaan dan pustakawan yang berperan sebagai biblioterapist memang belum ada acuannya. Tapi berdasarkan pengalaman penulis sebagai biblioterapist, bahwa bakat seorang terapist memegang peranan penting.
Saya percaya bahwa bakat yang didukung latar pendidikan bidang tertentu akan lebih melesatkan seseorang menjadi seorang ahli atau pakar. Bakat ini terkait karakteristik individu saat berinteraksi dengan dirinya dan orang lain. Terdapat keunikan dari sifat dasar manusia. berdasarkan pola-pola sidik jari, grafologi, dan numerologi, seseorang bisa menentukan dia berperan sebagai apa di dunia ini.

Hal ini penting, untuk menempatkan orang yang tepat, pada posisi yang tepat. Maka pelayanan yang diberikan jauh melebihi profesional. Profesional mengindikasikan bahwa kita bekerja sepenuh gaji bukan lagi sepenuh hati, sementara menjadi seorang expert/ ahli/ pakar justru kebalikannya.

Kepakaran seseorang ditunjang oleh bakat, passion, dan insight sehingga dalam memberikan pelayanan akan all out, sungguh-sungguh, ikhlas, dalam kondisi menyenangkan dan bahagia, karena sudah berada di habitatnya yang sesuai. Selama 3 tahun mendalami ilmu tes sidik jari, salah satu yang dapat memberdayakan SDM di berbagai bidang pekerjaan adalah konsep STIFIn sidik jari.

Orang yang paling pas berdasarkan hasil analisis STIFIn untuk berperan sebagai biblioterapist adalah orang sensing dengan kegemarannya membaca, menghafal dan mengingat (ensiklopedia 
berjalan) ditambah ketelatenannya dan sifat rajinnya. Orang Thinking dengan kesediaannya memberikan konsultasi yang mendalam hingga klien mengalami perubahan dan merasa nyaman, Thinking cocok sebagai konsultan terapist yang sangat analisis dan sistematis dalam memberikan report assessment, sementara yang paling baik memahami klien dengan melibatkan perasaannya adalah orang Feeling.

Feeling memang ditakdirkan menjadi seorang motivator/ inspirator bagi orang lain. Jika saja mau menggunakan terapist feeling, maka libatkan mereka yang berkebutuhan khusus dengan tipe feeling yang sudah sukses menjalani peran kehidupannya, sehingga akan menjadi motivator dan inspirator sejati bagi mereka yang mengalami kondisi serupa. Memang idealnya, biblioterapist memiliki relawan perwakilan dari masing-masing tipe kebutuhan khusus. Terakhir orang insting, yang berperan dalam hal membantu tanpa pamrih. Orang-orang insting mewakili tipe serba bisa namun serba nanggung, tetapi aksi cepat tanggap dalam membantu orang lain, jika insting ditempatkan di layanan biblioterapi ini, jangan dijadikan sebagai konselor atau biblioterapist, cukup menjadi orang kedua yang memberikan pertolongan.
Karakter tersebut secara sederhana bisa dikenali dari tipe golongan darah sebagai respon sesaat, antara lain A sama dengan Thinking, B sama dengan intuiting, $A B$ sama dengan sensing dan $O$ sama dengan feeling. Insting sendiri sebenarnya berada pada 4 jenis golongan darah tersebut.

Sementara intuiting, dapat dilibatkan dalam pembimbingan layanan biblioterapi membuat karya, novel, puisi, dan sebagainya. Setelah mengetahui personality bakat mesin kecerdasan, barulah kita jalankan misi menjadi seorang biblioterapist expert. Fokuslah pada satu bidang ini dan jadilah ahli dengan menambah jam terbang. Sebab, biblioterapi tidak bisa berdiri sendiri sebagai metode terapi, maka penting digali kemampuan praktik, meliputi:

\section{Kualifikasi:}

1. Bersertifikasi tes genetik otak, mesin kecerdasan STIFIn dan berbakat di salah satunya. Khusus untuk biblioterapist diutamakan dari Thinking dan Feeling.

2. Sarjana (S1) Ilmu perpustakaan yang pernah mendapat pelatihan biblioterapi.

3. Master (S2) Ilmu perpustakaan yang mendalami biblioterapi

4. Tenaga perpustakaan, pengasuh panti yang memenuhi syarat bakat.

5. Mengikuti lokakarya biblioterapist selama 3 bulan, in house training 1 bulan, dan on job training 3 bulan. Setelah itu boleh memiliki license 
biblioterapist jika sudah menangani klien selama 3 tahun.

6. Lulus tes uji kelayakan biblioterapist berkebutuhan khusus, secara tertulis maupun wawancara oleh pakar biblioterapist/ psikolog.

Sekali lagi, profesi biblioterapist adalah panggilan jiwa, yang dimotori oleh bakat seseorang, sehingga penulis sarankan para pengambil kebijakan tidak asal tunjuk orang untuk ditempatkan sebagai terapist/ konselor. Percayalah bahwa keberhasilan sebuah terapi terletak pada kemistri klien dan terapist yang "ngeklik”. Jika individu mau belajar, apapun bisa anda kuasai. Tapi jika individu belajar beradasrkan bakat lahirnya, ia akan menjadi ahli/ pakar yang mengalahkan seorang bergelar akademik tinggi tapi tanpa bakat di bidang tersebut. (Agustina, 2014, p. 17)

\section{Kompetensi:}

1. Mau belajar hal baru.

2. Memiliki keahlian komunikasi (membaca, menulis, memahami, bercerita, mempresentasikan), hypnosis*, hypnotherapi*, biblioterapi, analisis mendalam terhadap klien, memahami tipe berkebutuhan khusus.

3. Memiliki kedisiplinan dalam pendokumentasian

4. Bisa bekerjasama dalam tim

5. Memiliki kualitas pelayanan prima dan senang melayani.

6. Mampu memahami orang lain, sabar, ramah, enerjik dan spiritual.

7. Kreatif dan pantang menyerah.
Samuel A. Kirk (1911) dalam Marshall (1979) merekomendasikan untuk menstimulasi motivasi dan sesuatu yang berkenaan dengan keinginan mereka yang berkebutuhan khusus untuk maju sesuai dengan perkembangan saat ini, sebagai berikut:

1. Menyediakan bahan bacaan yang disesuaikan dengan kebutuhan mereka

2. Membuat para klien berkebutuhan khusus tersebut menyadari untuk hidup sukses

3. Mendorong mereka berprilaku mandiri tidak bergantung pada orang lain

4. Memberikan kemudahan untuk akses informasi dengan mudah/ terutama bacaan yang menarik bagi mereka.

5. Menyediakan buku- buku yang variatif dari segi subjek dan jumlahnya banyak.

6. Dorong mereka untuk membaca dalam rangka memeroleh informasi dalam memilih kebutuhan akan bacaannya.

7. Sediakan alat bantu visual pada waktu mereka melakukan seleksi.

8. Arahkan agar mereka membaca Surat kabar.

9. Sediakan berbagai pilihan sebagai pembanding apakah mereka tertarik pada bidang berita, cerita, petualangan, dan lain- lain

10. Miliki buletin atau majalah ( Marshall, 1982, p. 27)

Manajemen dan Praktik Layanan Biblioterapi di Perpustakaan Ramah Disabilitas untuk Membantu Klien Secara Inklusif

Melalui progam advokasi bantuan penyediaan koleksi untuk siswa yang 
memerlukan bantuan khusus Kirk dam Johnson, menyarankan untuk mengembangkan metode pendekatan kata dan independensi penentuan bahan bacaan yang komprehensif dan kompleks, rekomendasi dimaksud adalah sebagai berikut:

1. Melakukan pesiar ( jalan- jalan)

2. Pelabelan pada koleksi

3. Penyiapan perlengkapan alat akses untuk buku

4. Melakukan storytelling (berkisah) oleh pustakawan, guru, pengasuh, dan klien pada umumnya.
5. Membaca cerita

6. Melakukan diskusi informal

7. Mengasosiasikan kata- kata ke gambar

8. Mendramatisasikan buku cerita

9. Membuat booklet ( buku kecil ) dan buku skrip ( buku catatan)

10. Berbagai cara untuk memelihara buku

11. Membuat permainan dengan nomor, bahasa, warna, rumah, taman, dan pekerjaan

12. Membuat media informasi seperti buletin dan majalah

13. Pembicaraan melalui telepon.

14. Menggambar.

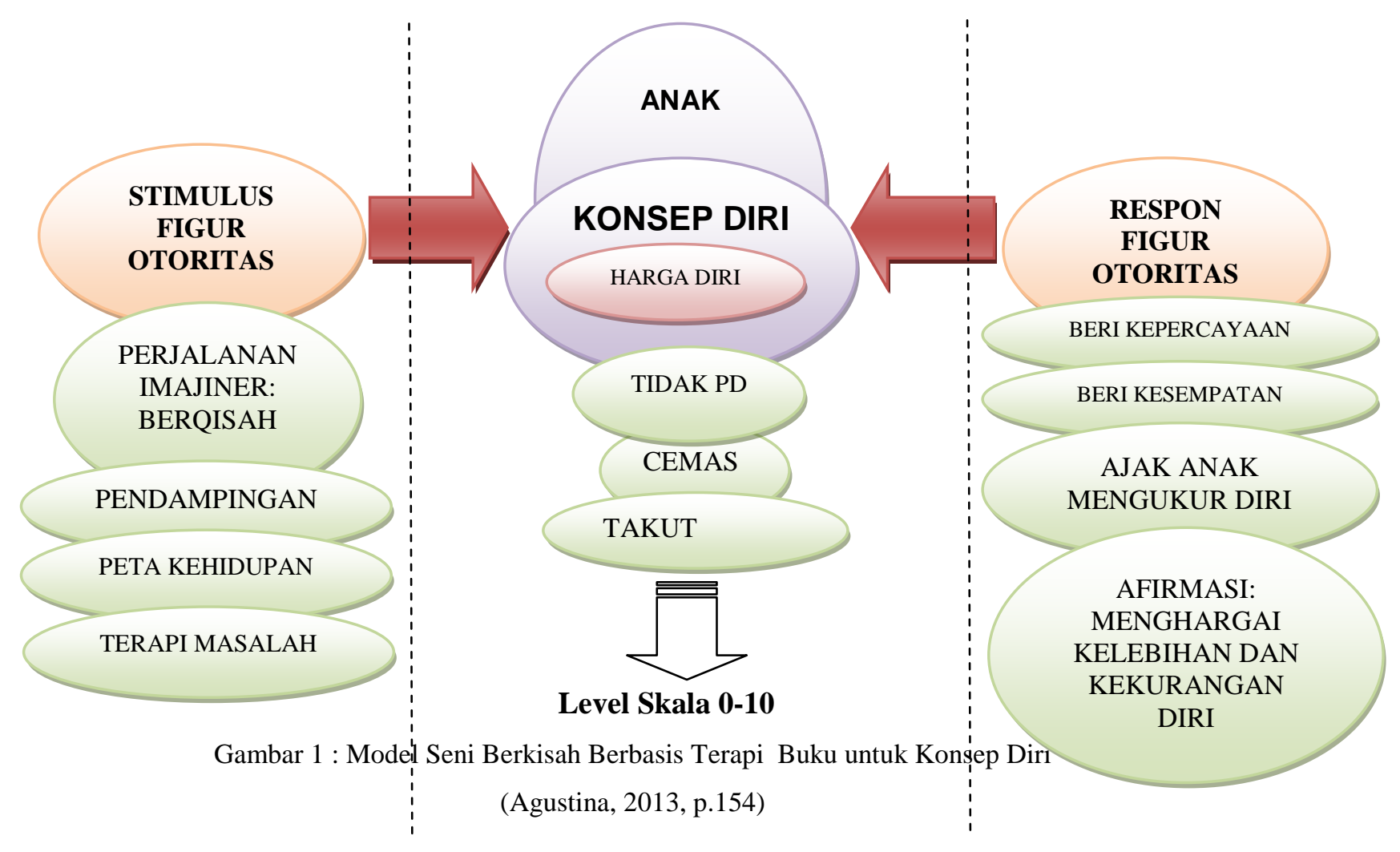

Berbicara biblioterapi bagi klien pada umumnya. Biblioterapi adalah berkebutuhan khusus tak terlepas dari berkisah, biblioterapi adalah membaca aktivitas berkisah. Pun berlaku bagi klien kisah, membaca buku non fiksi. semuanya 
selalu menjadi daya tarik tersendiri untuk menyampaikan nilai-nilai kehidupan. Tentang kearifan yang mendongkrak pembelajaran. Parkin mengatakan, "Pencerita pada masa lalu memberikan layanan yang tak ternilai dengan membantu orang untuk merasakan isu-isu yang rumit, dengan mengekspresikan apa yang tidak dapat terungkapkan, dan memberikan kenyamanan dan dukungan pada saat-saat sulit.” (Parkin, 2006, p.1 dalam Agustina, 2014, p.19).

Pustakawan biblioterapist penting memiliki kompetensi berqisah. "Berqisah merupakan keterampilan komunikasi yang membakar imajinasi dan daya khayal penyimaknya” (Parkin, 2006). Dalam kegiatan berqisah komunikasi instruksional persuasif melalui penggunaan bahasa, perumpamaan visual, membangun rasa empati dan kedekatan emosional denganklien berkebutuhan khusus. Mereka masih memerlukan bimbingan saat membaca buku juga saat merefleksikan isi buku dengan pengalaman-pengalamannya yang lebih luas, mengarah pada diskusi dan menghasilkan karya baru seperti puisi, prosa, laporan penelitian sederhana, bahkan cerpen dan novel. Menyampaikan qisah adalah menyampaikan nasihat dengan cara yang nyaman dan menyenangkan hingga masuk dalam pikiran alam bawah sadar (subconcious mind).
Dalam otak kita dikenal adanya area kritis. Letaknya diantara Conscious Mind dan Sub-Conscious Mind . Area kritis (critical area) itu suatu "perangkat” yang fungsinya sebagai penyaring (filter). Tugas area kritis adalah “menyaring” data yang berasal dari luar (yang masuk lewat panca indera) agar pesan tidak masuk begitu saja ke dalam Sub-Conscious Mind. Di beberapa buku, "Critical Area” ini sering juga disebut sebagai RAS (Reticular Activating System), yang lebih menyoroti pengaruh. Critical Area merupakan penampungan data sementara, sebelum data ditindaklanjuti untuk diteruskan ke SubConscious Mind. Apakah data yang masuk lewat panca indera tersebut mau dipertahankan atau dilenyapkan. Logika, etika, fokus, emosi, juga minat sangat berpengaruh terhadap fungsi filter dari Critical Area.

Terkait area kritis ini, jika seseorang yang berada dalam kondisi "Hypnos" dalam atau "Deep Trance", filter-nya akan terbuka "lebar”, qisah yang mengandung informasi (saran) yang berasal dari luar cenderung akan mudah memasuki Sub-Conscious Mind. Kondisi deep trance bisa kita jumpai saat 15 menit anak tertidur, tanda-tanda fisiknya, apabila diangkat tangannya, lalu dijatuhkan terasa sangat ringan tanpa ditahan, gerakan bola mata agak cepat, saat mata terpejam. Namun, dalam kondisi tersebut anak masih dapat 
diajak berbicara. Dualitas pikiran dapat

digambarkan sebagai berikut:
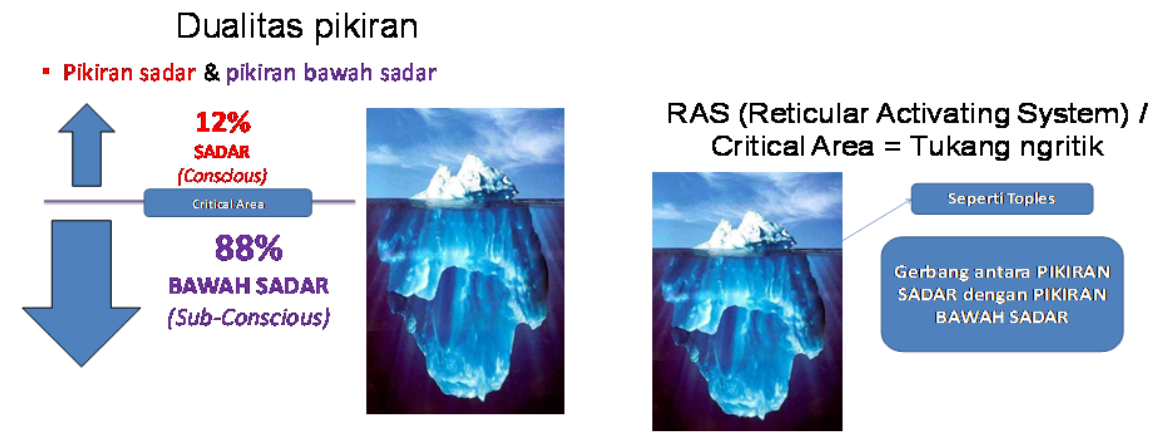

Gambar 2: Dualitas Pikiran

Terdapat banyak cara membuka area kritis, antara lain melalui emosi, konsentrasi, rileksasi (kondisi santai /relaks), repetisi (pernyataan yang diulangulang), kepercayaan penuh (belief) dari Otoritas dan kelompok, spiritual, juga melalui Hypnosis. Berqisah menjadi teknik tersendiri untuk mengolah emosi, konsentrasi, relaksasi, juga spiritual. Karena, apabila berqisah menjadi seni, secara otomatis pustakawan sekolah memainkan semua peranan panca indera anak didik, yaitu VAKOG. Mulai dari visual (mata), auditory (telinga), kinesthetic (otot gerak/ tangan dan kaki), olfactory (penciuman), gustatory (perabaan/kulit).
Apa manfaatnya membuka area kritis?. Terbukanya tutup toples area kritis berarti mengijinkannya informasi baru masuk ke area bawah sadar (Subconscious Mind). Di area inilah letaknya kekuatan diri manusia.

Apabila berqisah berbasis terapi buku hendak dilakukan untuk mengubah perilaku buruk pada anak, klien berkebutuhan khusus, pustakawan biblioterapist dan para pendidik harus berusaha masuk ke area bawah sadar ini. Sebab, alam bawah sadar (subconscious mind) ini lokus memori jangka panjang, emosi/persepsi, belief, kebiasaan, dan bahkan konsep diri. 
Alam bawah sadar memiliki pengaruh sembilan kali lebih kuat dibandingkan pikiran sadar (agustina, 2013). Pikiran bawah sadar selalu jadi pemenangnya. Mengubah kebiasaan, perasaan, kepribadian, keyakinan yang negatif, mengendalikan emosi, perilaku seseorang yang harus dilakukan adalah memrogram ulang pikiran bawah sadarnya. Sementara conscious mind (alam sadar), memorinya jangka pendek, tugasnya untuk identifikasi, membandingkan, analisa, rasionalitas, dan memiliki kekuatan kehendak untuk memutuskan sesuatu.

Pustakawan biblioterapist dapat melakukan beberapa cara untuk pemberdayaan pikiran bawah sadar hanya dengan mengasah keterampilan komunikasi. Terapi buku (Bibliotherapi) memang bukan merupakan terapi tunggal. Pustakawan biblioterapist perlu melatih diri untuk kemampuan komunikasi persuasif atau komunikasi figur otoritas, melalui Hipnosis.

Hipnosis merupakan suatu keadaan pikiran yang mengakibatkan perilaku “bawah sadar”, mudah di 'sentuh', daripada perilaku "sadar", perhatian terfokus, kepekaan indrawi yang luar biasa dengan perhatian terbatas, hilangnya otonomi akibat berkurangnya kontrol kesadaran, kerentanan terhadap respons paska hipnosis. Kondisi rileksasi pada anak dapat dilatih sejak dini lewat berqisah sebelum tidur, di dalam qisah terdapat sugesti yang menjadi salah satu prinsip hipnosis. (Agustina, 2013).

Di perpustakaan lingkungan pendidikan dapat disediakan layanan bibliotherapy, khusus untuk penanganan terapi buku secara personal. Dengan kursi khusus terapi yang nyaman, apabila perpustakaan di lingkungan pendidikan ingin memadukan metode terapi buku dengan hipnosis. Hipnosis yang dilakukan secara berkala untuk mengatasi suatu masalah disebut hipnotherapi. Hipnoterapi dapat mengatasi beberapa masalah, seperti:

\section{Mengubah Mental}

- Self Confidence \& Self Esteem

- Traumatic \& Phobia

- Drug Addiction

- Anodyne Awareness Smoking Cessation

- Weight Reduction Program

2. Menyembuhkan Psikosomatis

- Alergi

- Blood Presure

- Asthma

3. Membantu Proses Penyembuhan - Cancer

- AIDS

Saat pustakawan biblioterapist sudah mengondisikan anak masuk dalam kondisi rileks, ada ciri-ciri yang bisa dijadikan indikator, seperti jika pupil membesar, denyut nadi melambat, pernapasan berubah, bentuk wajah halus dan santai, tanggapan penuh perhatian, nyaman dan rileks, refleks, perubahan pada 
mata / menutup mata, tubuh tidak mampu bergerak, perubahan mutu suara, perubahan indra, otot, tubuh.

Untuk menggabungkan metode terapi buku dengan teknik hipnosis memang memerlukan latihan khusus. Namun, penting untuk diketahui bahwa seorang pustakawan biblioterapist yang berbakat dalam membangun hubungan komunikasi dengan klien berkebutuhan khusus pasti mudah melakukannya. Sementara, bagi pustakawan yang merasa tidak berbakat untuk memahami jiwa anakanak, lebih baik berkoordinasi dengan guru Bimbingan Konseling atau psikolog untuk saling membantu menentukan solusi terbaik bagi setiap permasalahan perilaku pada klien disabilitas atau berkebutuhan khusus.

\section{SIMPULAN}

Keterampilan utama pustakawan biblioterapist adalah menentukan apakah sebuah buku atau literatur layak dipergunakan dalam terapi buku atau tidak, kemampuan berqisah, mengembangkan diskusi untuk membangun pesan/ hikmah dari klien dan membuat laporan tertulis. Hal tersebut membutuhkan latihan, terutama keahlian membaca dari pustakawan. Sehingga, pustakawan akan melakukan pengadaan, pengolahan, pengorganisasian literatur khusus untuk dipergunakan dalam terapi buku. Selanjutnya, laporan hasil diskusi buku dapat dikoordinasikan dengan guru wali kelas atau guru Bimbingan Konseling. Laporan tersebut membantu guru BK membuat report assessement untuk mengetahui perkembangan perilaku klien dan klien berkebutuhan khusus.

\section{DAFTAR PUSTAKA}

Agustina, Susanti. (2011). Konstruksi Sistem Pembelajaran Kenal Pustaka. Bandung: Fikom Unpad: Tesis.

Agustina, Susanti. (2014). Perpustakaan Prasekolahku Seru: Seni Berqisah Berbasis Terapi

Buku Untuk Anak Dini Usia. (pp102-111). Bandung: CV. Restu Bumi Kencana.

ALA. (2008). The Standards for Proficiencies for Instruction Librarians and Coordinators. Retrieved July 23, 2011, from www. Ala.org/ala/mgrps/ divs/ acrl/ profstandards. Cfm.

Bunanta, Murti.(2009). Buku, Dongeng, dan Minat Baca. Jakarta: Murti Bunanta Foundation.

Clarke, Jean M. (1988). Reading Therapy (pp.1-12, 106-123). London: Library Association Publishing.

Ellis, gail et all. (1991). The storytelling handbook for primary teachers (pp.1-31). Middlesex: penguin English.

Fjallbrant, Nancy. (1978). User education libraries. London: Clive Bingley.

Juhana, Hendri. (2012). 96,4 Menit Menjadi Pendongeng: Bacaan Wajib Pecinta Dongeng. Bandung: Motekar.

Parkin, Margaret.(2006). Tales fo Change: Using Storytelling to Develop 
People and Organizations. Bandung: Kaifa.

Prater, Mary Anne., et all.(2006). Using Childrens Books as Bibliotherapy for At-Risk Students: A Guide for Teachers (Vol.50 No 4). Retrieved February 11,2014, from ProQuest Research Library.

Qisty, Syifa Naufal. (2011). Pengaruh Mendongeng Dalam Memotivasi Kegiatan Membaca Anak di Kebukit. Fikom Unpad: Skripsi.

Safaria, Triantoro. (2004). Terapi KognitifPerilaku Untuk Anak. Yogyakarta: Graha Ilmu.

Sarumpaet, Riris K. (1976). Bacaan Anakanak :Suatu Penyelidikan Pendahuluan Ke Dalam Hakekat Sifat dan Corak Bacaan AnakAnak Serta Minat Anak Pada Bacaannya. Jakarta: PT Dunia Pustaka Jaya. 